\title{
Sedimentation rates and provenance analysis in the Southwestern Okinawa Trough since the mid-Holocene
}

\author{
LI ChuanShun ${ }^{1,2}$, JIANG Bo $^{1,2,3 \dagger}$, LI AnChun ${ }^{1}$, LI TieGang ${ }^{1}$ \& JIANG FuQing ${ }^{1}$ \\ ${ }^{1}$ Key Laboratory of Marine Geology and Environment, Institute of Oceanology, Chinese Academy of Sciences, Qingdao 266071, \\ China; \\ ${ }^{2}$ Graduate University, Chinese Academy of Sciences, Beijing 100049, China; \\ ${ }^{3}$ China Ocean Press, Beijing 100081, China
}

As a high-sedimentation rate depocenter along the path of the Kuroshio Current, the southwesternmost part of the Okinawa Trough is a key area to understand the Kuroshio history and sediments transportation. A 34.17-m-long sediment core was obtained by the advanced piston corer of Marco Polo/IMAGES XII MARION DUFRESNE during the May 2005 from the Southern Okinawa Trough at site MD05-2908. The recovered sediments were analyzed by $A M S{ }^{14} \mathrm{C}$ dating, coarse size fraction $(>63 \mu \mathrm{m})$ extraction and moisture content determination in order to study its sedimentation flux and provenance. The depth-age relationship of core MD05-2908 was well constrained by $17{ }^{14} \mathrm{C}$ dating points. The sediments span across the mid-Holocene (6.8 ka B.P.) and have remarkablely high sedimentation rates between 1.8 and $21.2 \mathrm{~m} \mathrm{ka}^{-1}$, which is well consistent with the modern observations from sediment traps. We identified five $70-200$ a periods of abnormally rapid sedimentation events at $6790-6600$ a B.P., $5690-5600$ a B.P., $4820-4720$ a B.P., $1090-880$ a B.P., and $260-190$ a B.P., during which the highest sedimentation rate is up to $21.2 \mathrm{~m} / \mathrm{ka}$. In general, the lithology of the sediments were dominated by silt and clay, associated with less than $5 \%$ coarse size fraction $(>63 \mu \mathrm{m})$. As the most significant sediment source, the Lanyang River in northeastern Taiwan annually deliver about $10 \mathrm{Mt}$ materials to the coastal and offshore region of northeast Taiwan, a portion of which could be carried northward by currents toward the study area. Therefore, we concluded that the $\mathbf{5}$ abnormally rapid sedimentation events may be related to intensified rainfall in Taiwan and thus increased materials to our study area at that time. However, a few extreme-rapid sedimentation events cannot be explained by normal river runoff alone. The large earthquakes or typhoons induced hyperpycnal discharge of fluvial sediment to the ocean may also act as a potential source supply to the Okinawa Trough.

Southwesternmost Okinawa Trough, mid-Holocene, sedimentation rates, sediment source

The sedimentary records from continental margins represent an ideal archive to study various sedimentary processes as well as for deciphering the past fluctuations in the climate system and possible forcing mechanisms. Owing to its location, geomorphology and hydrodynamic conditions, the southernmost part of the Southern Okinawa Trough (SOT) acts as an efficient sink for sediments from Taiwan and the East China Sea shelf. The region is also known for the Kuroshio Current, which turns northwestwards and branches off from its mainstream before continuing to flow to the North Pacific. The abrupt change in seafloor topography further causes the Kuroshio waters to intrude and upwell onto the East China Sea continental slope. The region thus provides an excellent opportunity to study the seawater

\footnotetext{
Received July 18, 2008; accepted November 15, 2008; published online January 20, 2009 doi: 10.1007/s11434-009-0010-0

Corresponding author (email: bjiangh@163.com)

Supported by National Basic Research Program of China (Grant No. 2007CB815903), Key Project of National Natural Science Foundation of China (Grant No. 90411014) and National Natural Science Foundation of China (Grant Nos. 40776030 and 40506016 )
} 
exchange process and its associated nutrient transport mechanism when Kuroshio waters intrudes into the East China Sea ${ }^{[1-10]}$. One unusual feature of the SOT is that high sedimentation rates are located approximately in the lower trough, deeper than $1000 \mathrm{~m}$ (ranging from 0.25 to $0.52 \mathrm{~cm} \mathrm{a}^{-1}$ estimated from the excess ${ }^{210} \mathrm{~Pb}$ profiles of cores) while low sedimentation rates are generally in the upper trough, shallower than $1000 \mathrm{~m}^{[11]}$. Based on results from a site $1202\left(24^{\circ} 48.24^{\prime} \mathrm{N}\right.$, $122^{\circ} 30.00^{\prime} \mathrm{E}$ ) of ODP Leg 195 in the SOT, the sedimentation rate has always been high, reaching $325 \mathrm{~cm} \mathrm{ka}^{-1}$ $\left(0.325 \mathrm{~cm} \mathrm{a}^{-1}\right)$ since the late Holocene ${ }^{[12]}$. Therefore, the SOT is apparently an area of high-sedimentation rate depocenter along the path of the Kuroshio Current. Furthermore, the lower slope $(>1000 \mathrm{~m})$ sediments consist almost entirely of silty mud ${ }^{[13]}$; for instance, mud accounts for over $97 \%{ }^{[14]}$, while the upper slope $(<1000 \mathrm{~m})$ sediments are composed of sand with little mud ${ }^{15]}$. The large supply of terrestrial sediments from Taiwan and China mainland appears to be sufficient to account for the accumulation in the high-sedimentation-rate in the SOT. Nevertheless, the issue about the source of the SOT sediment has been debated for over two decades. Earlier efforts to identify the sources (e.g. the Changjiang or Taiwan's rivers) and transport pathways of the SOT sediment were based on diverse tools, e.g. chemical characteristics, mineralogy and physical properties of the sediments. Besides the primary production in the water column $^{[16-19]}$, the sediments of SOT originate from two major terrestrial sources, Chinese mainland $\frac{[16,19,20]}{}$ and

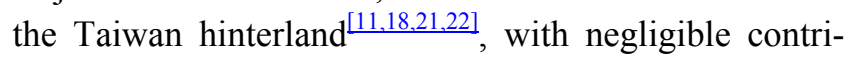
butions from the Ryukyu Island Arc. Nonetheless, studies conducted in the past have mainly based on surficial sediments and particles collected by sediment traps, with scant attention to the temporal variations of the provenance and transport pathways of fine-grained terrigenous sediments. It is therefore the purpose of this study to perform various measurements of a $34.2 \mathrm{~m}$ sediment core collected from the SOT in order to (1) determine the temporal variations in the sediment flux, (2) examine the source and transport mechanisms of the sediments, and (3) evaluate the significance of episodic events (i.e. flood runoff and large earthquakes) as they might be reflected in observed flux extremes. It is the hope that results from this study can help delineate the fate of particle transport in the region.

\section{Material and methods}

Between May 15 and June 8, 2005, the gravity core MD05-2908 used in this study was recovered from the continental slope of southern Okinawa Trough during the IMAGES XIV, MD-155-Marco Polo 2 cruise of the $\mathrm{R} / \mathrm{V}$ Marion Dufresne of the French Polar Institute (IPEV). The core, $34.2 \mathrm{~m}$ in length, is located at $24^{\circ} 48.04^{\prime} \mathrm{N}, 122^{\circ} 29.35^{\prime} \mathrm{E}$, with a water depth of $1275 \mathrm{~m}$ (Figure 1). The sediments in core MD05-2908 consist of homogenous dark gray hemipelagic clay and fine silt-sized sediments.

A total of 854 samples were analyzed for water content at $4 \mathrm{~cm}$ sampling intervals. The percentage of the coarse fraction $(>63 \mu \mathrm{m})$ in the sediments was analyzed by 419 samples at $8 \mathrm{~cm}$ intervals: After being dreid at $60^{\circ} \mathrm{C}$ for $48 \mathrm{~h}$, the samples were weighed, suspended in deionized water and then wet-sieved through a 250-mesh screen to separate the coarse fraction and calculate the percentage by weighting.

More than $4 \mathrm{mg}$ specimens of surface water-dwelling planktonic foraminifers, including $G$. sacculife and $G$. ruber, from the $>150 \mu \mathrm{m}$ size fraction of 17 selected intervals were sent to the NOSAMS, Institute of Woods Hole Oceanographic Institution, USA for AMS dating (Table 1). All ${ }^{14} \mathrm{C}$ ages were converted to "calendar ages" using CALIB Program (version 5.0) ${ }^{[23]}$. In the conversion, we adopted a $\Delta R=35 \pm 25$ years (the local difference in reservoir age from 400 years in the southern Okinawa Trough) as determined from annually banded corals of Ishigaki Island. The calibrated ages were then converted into thousand years before present (BP) (ka before AD1950).

\section{Results}

\subsection{Core description and sedimentology study}

The sediments of MD05-2908 are mainly composed of fine terrestrial clay and silt. The coarse fraction $(>63$ $\mu \mathrm{m})$, made up chiefly of slate fragments, quartz grains, chlorite and mica flakes, only accounts for $\sim 2 \%$ of the sediments. According to the changes of coarse fraction content, the core was divided into 4 sections. The upper section $(0-850 \mathrm{~cm})$ is mainly composed of fine-grained sediments, with thin interbedding of silty sand and sandy silt. Sediments of $850-2300 \mathrm{~cm}$ section are exclusively of hemipelagic mud without any visible silt-sand layer. 


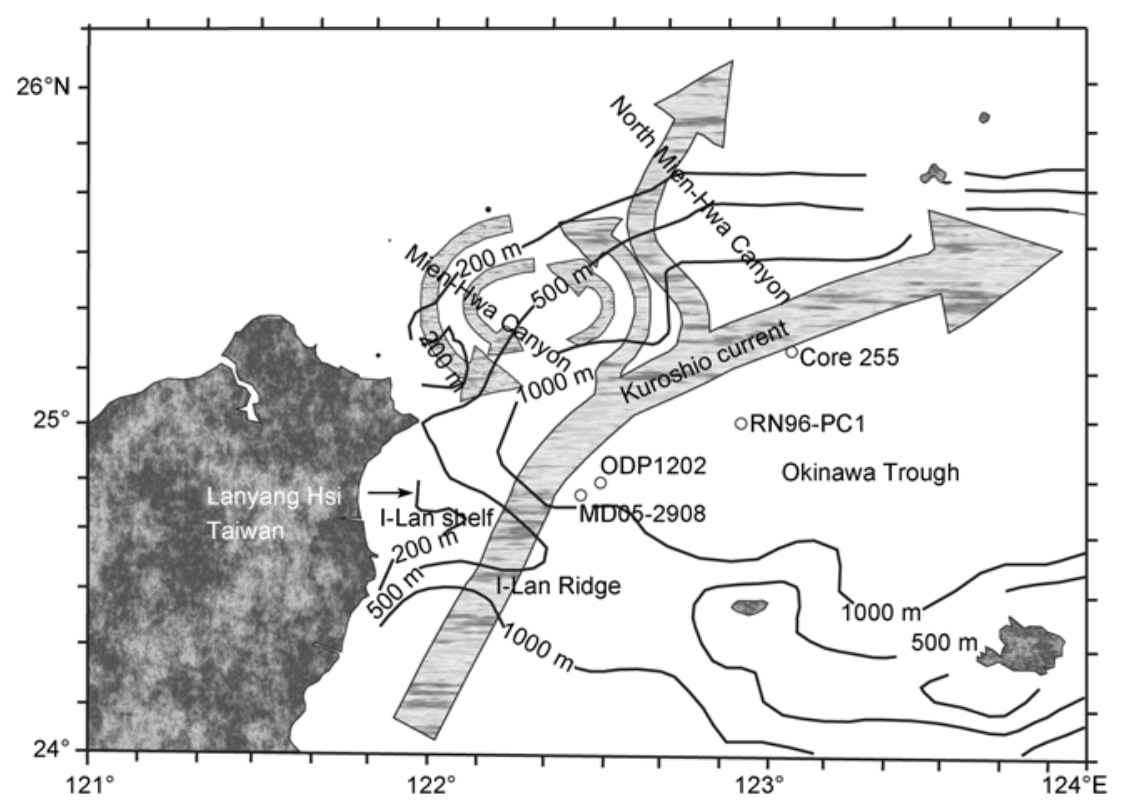

Figure 1 Topography of the Southern Okinawa Trough and the location map of core MD05-2908.

Table 1 AMS ${ }^{14} \mathrm{C}$ data of core MD05-2908 in the southernmost Okinawa Trough

\begin{tabular}{|c|c|c|c|c|}
\hline Core depth $(\mathrm{cm})$ & AMS ${ }^{14} \mathrm{C}$ age $(\mathrm{a})$ & Calendar age (a B.P.) & Material & Sedimentation rate $\left(\mathrm{cm} \mathrm{a}^{-1}\right)$ \\
\hline 13 & $470 \pm 30$ & 57 & & 0.228 \\
\hline 105 & $600 \pm 45$ & 191 & & 0.687 \\
\hline 213 & $650 \pm 30$ & 262 & & 1.521 \\
\hline 413 & $900 \pm 25$ & 489 & & 0.881 \\
\hline 613 & $1370 \pm 40$ & 876 & & 0.517 \\
\hline 813 & $1570 \pm 25$ & 1092 & & 0.926 \\
\hline 909 & $2080 \pm 40$ & 1615 & & 0.184 \\
\hline 1309 & $2850 \pm 30$ & 2571 & & 0.418 \\
\hline 1501 & $3200 \pm 35$ & 2958 & G. sacculife + G. ruber & 0.496 \\
\hline 1853 & $3760 \pm 30$ & 3648 & & 0.510 \\
\hline 2005 & $3980 \pm 25$ & 3933 & & 0.533 \\
\hline 2253 & $4550 \pm 40$ & 4715 & & 0.317 \\
\hline 2405 & $4630 \pm 30$ & 4816 & & 1.505 \\
\hline 2621 & $5270 \pm 40$ & 5599 & & 0.276 \\
\hline 2805 & $5370 \pm 35$ & 5693 & & 1.957 \\
\hline 3005 & $6200 \pm 45$ & 6600 & & 0.221 \\
\hline 3405 & $6360 \pm 40$ & 6789 & & 2.116 \\
\hline
\end{tabular}

$2300-2750 \mathrm{~cm}$ section is composed of hemipelagic mud with three insignificant thin layers of very fine sand and silt. A fine sand layer in $2347-2350 \mathrm{~cm}$, associated with feldspar, quartz, chlorite and mica flakes could be correlated with the other two sand layers in 2579-2584 $\mathrm{cm}$ section and $2728-2735 \mathrm{~cm}$ section. The coarse fraction of these three intervals increased to more than $13.12 \%, 9.28 \%$ and $10.30 \%$ with higher sedimentation rates, and the scarcity of foraminifers in these intervals due to dilution by enormous terrestrial material has caused difficulty in obtaining enough specimens for ${ }^{14} \mathrm{C}$ - dating and isotopic analysis. The lower section (2750$3414 \mathrm{~cm}$ ) is also mainly composed of fine-grained sediments with less than $\sim 2 \%$ coarse fraction (Figure 2(b)).

\subsection{Age model and sedimentation rates}

The depth-age relationship of core MD05-2908 is well constrained by the $17{ }^{14} \mathrm{C}$-dating points (Figure 2(a)). An age model was then obtained by linearly interpolating between the control points. The $34.2 \mathrm{~m}$ core has a continuous record of the past 6800 years, and so high-resolution record is a good material to research the millen- 

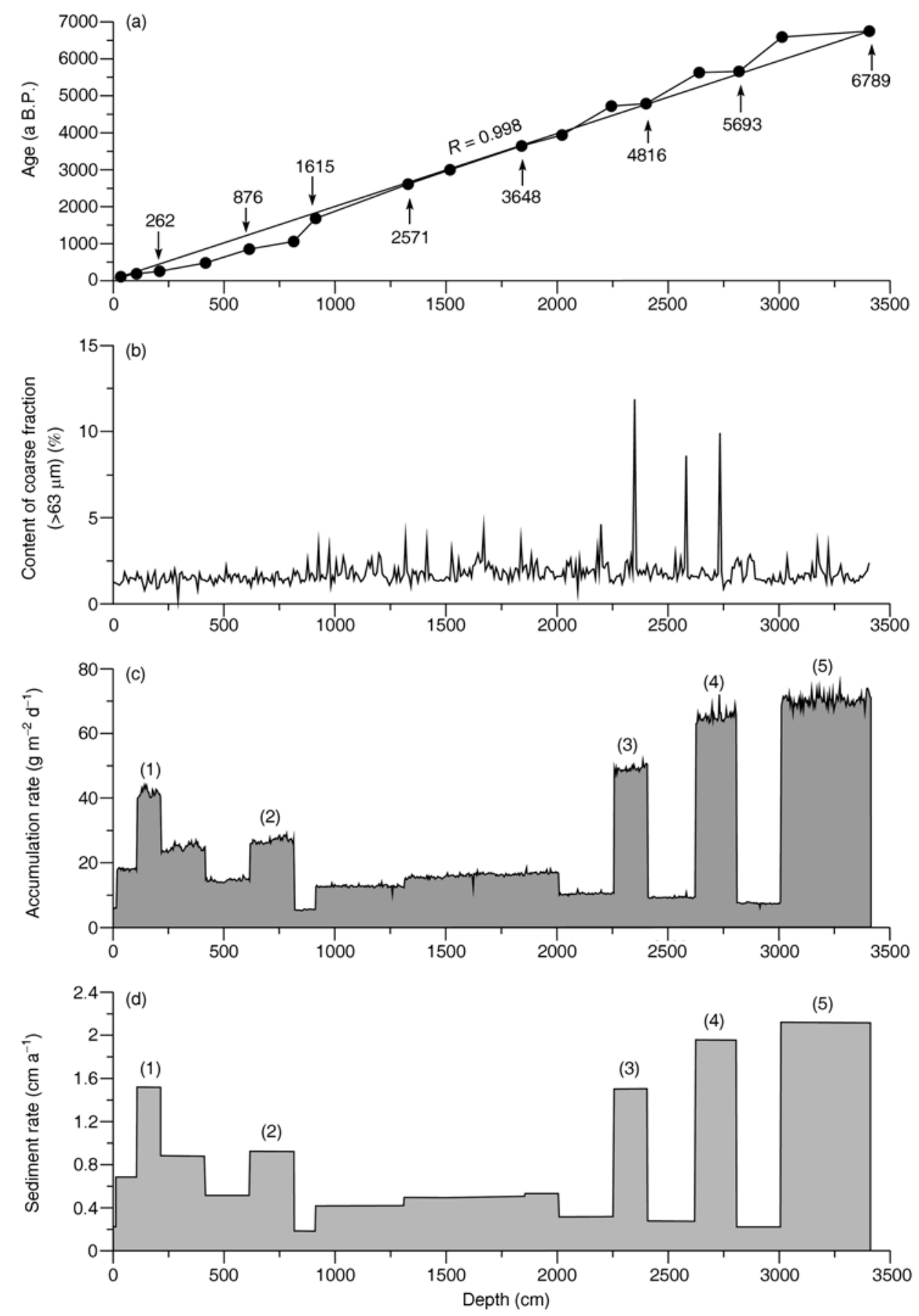

Figure 2 Sediment characteristics during the past 6800 years. (a) Depth-age relationship of core MD05-2908 based upon AMS ${ }^{14} \mathrm{C}$-dating of 17 samples; (b) variation in percentage of coarse size fraction (>63 $\mu \mathrm{m})$; (c) accumulation rate; (d) sedimentation rate.

nial to decade scales of the historic climate change. Sedimentation rates were integrated between depths of ${ }^{14} \mathrm{C}$-datings using converted ages. They varied largely from 1.84 to $21.16 \mathrm{~m} \mathrm{ka}^{-1}$. Such high sedimentation rates are unprecedented in the Okinawa Trough and somewhat unexpected. Previously published results from southern Okinawa Trough sites recorded sedimen- tation rates of about $50 \mathrm{~cm} \mathrm{ka}^{-1}$. For instance, Site $\mathrm{RN} 96-\mathrm{PC} 1$ at $24^{\circ} 58.5^{\prime} \mathrm{N}, 122^{\circ} 56.1^{\prime} \mathrm{E}$ records an average rate of $40 \mathrm{~cm} \mathrm{ka}^{-1[24]}$ while at a northern site, core 255 $\left(25^{\circ} 12^{\prime} \mathrm{N}, 123^{\circ} 07^{\prime} \mathrm{E}\right)$ has an average rate of $60 \mathrm{~cm} \mathrm{ka}^{-1}$ for the last $7.3 \mathrm{ka}^{[25]}$, site 1202 of ODP Leg 195 shows $350 \mathrm{~cm} \mathrm{ka}^{-1}$ since the Holocene ${ }^{[10]}$. For the similar time interval of the last $6.8 \mathrm{ka}$, MD05-2908 has accumulated 
$34 \mathrm{~m}$ sediment, showing an average sedimentation rate, one order higher than at other sites. The large accumulation of sediments at this site suggests that MD05-2908 is located at a localized deposition center. Present mass fluxes near core MD05-2908 are estimated to be $20 \mathrm{~g}$ $\mathrm{m}^{-2} \mathrm{~d}^{-1}$, well consistent with the sedimentation fluxes calculated here (Figure 2(c)).

Based on the $17{ }^{14} \mathrm{C}$ dates, we also identified five $70-200$ a periods of abnormally rapid sedimentation events at $6790-6600$ a B.P., $5690-5600$ a B.P., $4820-4720$ a B.P., $1090-880$ a B.P., and $260-190$ a B.P., at $3405-3005 \mathrm{~cm}, 2805-2621 \mathrm{~cm}, 2405-2253$ $\mathrm{cm}, 813-613 \mathrm{~cm}$ and $213-105 \mathrm{~cm}$ respectively. At that time, the highest sedimentation rate is up to 21.2 $\mathrm{m} / \mathrm{ka}$.

\section{Discussion}

\subsection{Sediments sources}

Core MD05-2908 lies at the southern Okinawa Trough with a high sediment rate of about $5 \mathrm{~m} / \mathrm{ka}$ from the middle Holocene, which is much higher than those observed in a similar marginal sea environment, such as the submarine canyons off Washington shelf ${ }^{[26]}$, the Baltimore Canyon off the east US coast ${ }^{[27]}$, the western Gulf of Mediterranean Sea ${ }^{[28,29]}$ and the SEEP area ${ }^{[30,31]}$. As a component of the Kuroshio Edge Exchange Processes (KEEP, 1989-1994) and Kuroshio-East China Sea Shelf Exchange Processes (KEEP II, 1994-1997) integrated programs conducted in Taiwan, time-series sediment traps and current meters were deployed in, and recovered from the slope area between the southern ECS shelf and the South Okinawa Trough for measurements of particulate fluxes, particle size distributions, compositions, stable isotopes, radionuclides and currents. Researchers have documented that the major components of the trap samples are mainly composed of fine terrestrial clay and silt ${ }^{[18]}$. A large portion of the particulates collected by traps in the canyon was probably transported along the isobaths or topographic contours from the canyon outlet toward the southwest rather than directly into the trough based on the high mass fluxes observed at the southwest of the Mien-Hwa Canyon and the available current meter data. Based on profiles of ${ }^{210} \mathrm{~Pb}$ and ${ }^{137} \mathrm{Cs}$ in 47 box cores collected from the SOT, Huh et al. ${ }^{[18]}$ had delineated spatial distribution of sedimentation rates and calculated sediment budget in the
SOT, the highest sedimentation fluxes lies at $24^{\circ} 50^{\prime} \mathrm{N}$, $122^{\circ} 30^{\prime} \mathrm{E}$, and the core MD05-2908 is situated very near the depocenter.

Today, fluvial runoff from the mountain ranges of Taiwan is the main source of detrital sediment supply to the southern Okinawa Trough, resulting from high erosional gradients and heavy summer rain falls ${ }^{[22]}$. In northern Taiwan, drainage of the mountain areas is basically achieved by the Lanyang River, whose mouth is directly situated adjacent to the southern Okinawa Trough. Annual total sediment yield amounts to $10 \mathrm{Mt}^{[32]}$. Parts of the fluvial suspensions are entrained and transported by the Kuroshio Current and transferred to the deep by the suction effect of the cyclonic eddies north of Taiwan, making it a major source of sediment supply to the trough $\underline{[22,33,34]}$. Spatially, the sediment fluxes exhibit a seaward decline from northeastern Taiwan to the central trough. On the continental slope, however, the flux increases with water depth, this was usually found in marginal seas, implying strong lateral transport of lithogenic particles. The temporal variation has a strong positive correlation with water runoff from the Lanyang River, whereas the highest fluxes were associated with typhoon-induced floods and, occasionally, with large earthquakes ${ }^{[22]}$. Furthermore, the abnormally high fluxes observed on the lower slope north to the I-Lan Shelf and Ridge demonstrated that the depositing environment is very dynamic, which will always cause sediment redistribution and then contribute sufficient sediments to the SOT.

There are three major current systems involved in the circulation of the ECS ${ }^{[35]}$ : (1) The Changjiang Coastal Current (CCC) flows southward along the coast of mainland China, the Changjiang annually delivers $478 \mathrm{Mt}$ of sediment onto the ECS shelf, and a substantial fraction of the fine-grained sediments is transported southward along by the CCC or tidal currents. In the northernmost section of the Taiwan Strait, the sediments are transported eastward to enter the Okinawa Trough $\stackrel{[36,37]}{ }$. (2) The Taiwan Warm Current (TWC) flows northward along Taiwan Strait, it is relatively stronger in the summer and weaker in the winter. In summer, the strong TWC is expected to bring fluvial sediments exported from Changjiang and western Taiwan's rivers to Okinawa Trough. In winter, monsoon-driven CCC flows southward and causes downwelling of nearshore waters, whereas the northward-flowing TWC causes upwelling. With these two vertical circulation cells, fine sediment transport is constrained to areas shoreward of the up- 
welling regime ${ }^{[38,39]}$. (3) The Kuroshio current, the main part of the Kuroshio enters the Okinawa Trough northeast of Taiwan across the I-Lan Ridge and delivers sediments to the $\mathrm{SOT}^{[40]}$, but low mean fluxes obtained from sediment traps indicate that the Kuroshio water was relatively "clean" "41]. As Kuroshio approaches northeastern Taiwan, it impinges on the shoaling East China Sea shelf; thereafter the Kuroshio mainstream turns northeastward almost along the shelf break. Part of the Kuroshio water intrudes onto the shelf above the Mien-Hwa Canyon and forms a branch current, called the Kuroshio Branch Current (Figure 1). On the western side of the branch current, a cyclonic eddy (about $70 \mathrm{~km}$ in diameter) is generated over the shelf-slope as a result of the westward deflection of part of the branch current. On the other hand, the upwelling and the eddy over the canyon may facilitate offshore and down-slope transport of sediments from the ECS shelf to the Okinawa Trough. From this circulation pattern it becomes clear, core MD05-2908 receives such tremendous amounts of clayey-silty sediments, as it lies at the end of the complex local Kuroshio Current structure on the northern slope of the I-Lan Ridge, where sediment transport energy gets lost and particulate loads settle out.

\subsection{The five abnormally rapid sediment events}

Apart from source strengths, a variety of factors have been considered to be regulating the sediment fluxes in the seas, such as primary production ${ }^{[30,42-44]}$, the supplies of storm-driven river sediment ${ }^{[45]}$, the re-suspension of sediments caused by the high-energy waves or the tide ${ }^{[46-48]}$ and the turbidity currents caused by large earthquakes ${ }^{[22]}$. Owing to the natural forces mentioned above, medium- to large-scale submarine mass movements can occur and thus play a very important role in transporting terrigenous sediment to deep sea basins. The bathymetric map of the southern Okinawa Trough shows that there are two submarine canyons (A and $\mathrm{C}$ in Figure 3 ). Between these two submarine channels, there is a concave depression (B in Figure 3) due to slope failure. The northern submarine canyon ( $\mathrm{C}$ in Figure 3 ) is active today and has a point-source following the onland Lanyang River which originates from the accretionary wedge slate belt in the western part of Central Range of northern Taiwan (Figure 3). The southern submarine canyon (A in Figure 3) has no active source today. The canyon A can be traced to the continental shelf $(150 \mathrm{~m}$ in depth). Since there is no major rivers except the Lanyang River north of $24^{\circ} 30^{\prime} \mathrm{N}$, the submarine canyon A

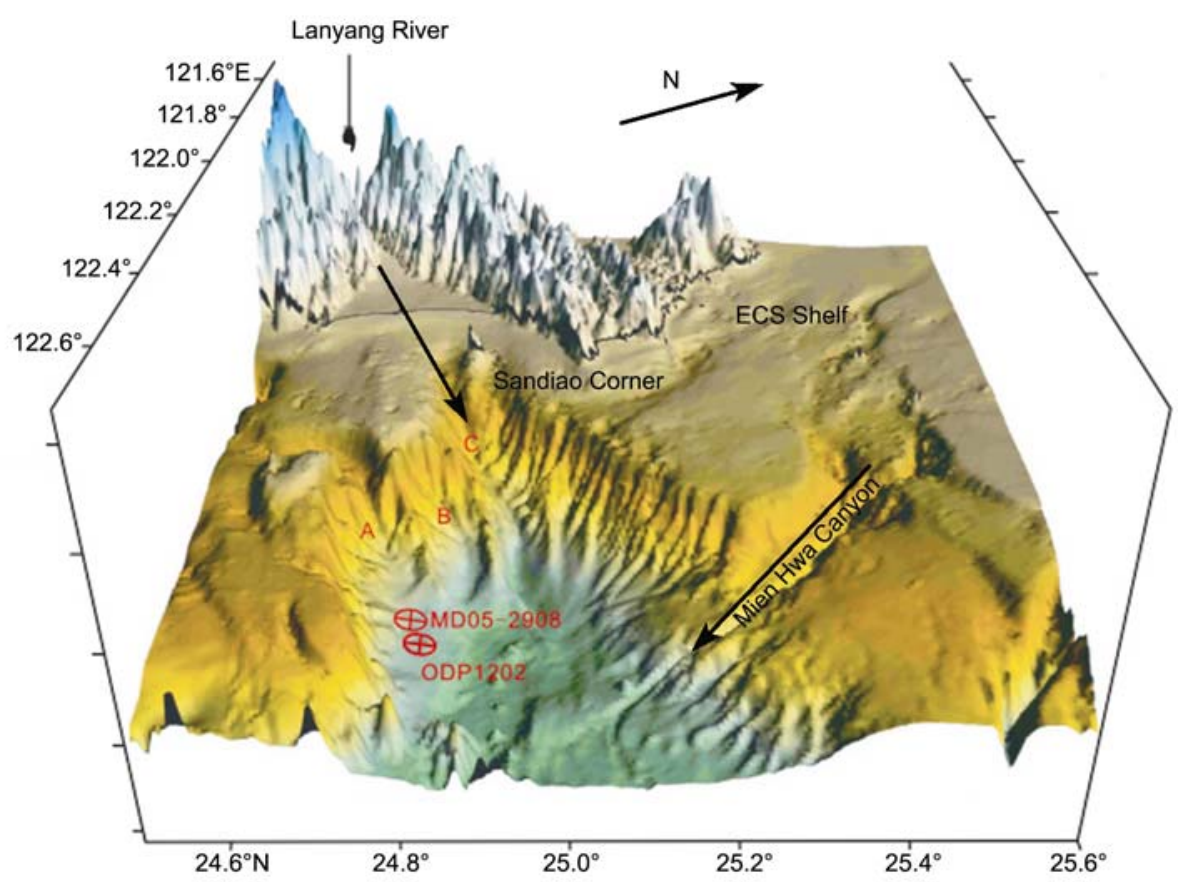

Figure 3 Topography of the Southern Okinawa Trough and northeast corner of Taiwan looking from the axis of the trough toward the Lanyang River and its delta plain on northeast Taiwan. The map was generated from the digital data compiled in Wei $\frac{110]}{\text { with }}$ exaggerated elevation. The location of core MD05-2908 and Site 1202 are marked by the red circle-cross symbol. Three canyons (A, B, and C) indicate major conduits that supply sediments to the southern Okinawa Trough. 
could represent a paleo-channel of this river during the last glacial time before channel migration in the Holocene due to sea-level rise. Therefore, the sediments eroded from the Central Range were transported to the site of core MD05-2908 by submarine channel transportation and/or slope failures, and then finally deposited in the southern Okinawa Trough. Sediments carried by rivers of eastern Taiwan could have deposited in the shallow I-Lan shelf, water depth at which is less than $200 \mathrm{~m}$ (from Liu et al. unpublished records of thin stratum section), and then transported to the deep sea basin through submarine channel erosion or slope failures due to frequent earthquakes induced by plate convergence/collision and extension of the southwestern Okinawa Trough off NE Taiwan. Because of strong dilution of enormous terrestrial materials, the influence on the change of sedimentation flux contributed by the primary production, is very limited in the study area ${ }^{[16-49]}$.

Usually, the exceptional high sediment flux could be attributed to episodic events, for example, typhoon passages, which always cause ample rainfall induced high runoff and sediment discharge, and sediment fluxes that were observed during typhoon passages accounted for more than $50 \%$ of the long-term flux ${ }^{[31,48]}$. Once typhoons struck Taiwan, heavy rainfall always caused high runoff together with huge sediment export from the land, thus contributing to the source of settling sediments. As high uplift and denudation rates, Taiwan is an important source for sediments to its around seas, and about $75 \%$ sediments were transported during typhoon passages ${ }^{[50,51]}$. It is only $70 \mathrm{~km}$ far from the studying area to the shore. Moreover, the three canyons are important conduits for sediments delivering from I-Lan shelf to Okinawa Trough. Therefore, output of Lanyang River could transit rapidly toward south of the Okinawa Trough, and high energy wave could induce materials which accumulate at I-Lan Continental Shelf and top of continental slope to re-suspend and further transport toward south of the Okinawa Trough. Thus we can see that such episodic small-river floods could account for much of the annual sediment flux to the continental shelf and slope ${ }^{[52]}$. Therefore, increase of sediment rate at the core MD05-2908 more probably resulted from climate events, such as typhoon, rainstorm or continual precipitation. Seventeen AMS ${ }^{14} \mathrm{C}$ data show that the sediment rate between $6.8 \mathrm{ka}$ B.P. and $4.0 \mathrm{ka}$ B.P. is relatively low and there are three obviously high rate sedimentation events during this period, i.e.6790-6600 a B.P., 56905600 a B.P., $4820-4720$ a B.P. respectively. The sedimentation rate during the period of $4.0-1.1 \mathrm{ka}$ B.P. is relatively steady. Sedimentation rate apparently increased around 1000 a B.P., reflecting the evolution of the Lanyang estuary and increased land erosion due to human activities, such as farming and deforestation. There are two high sediment rate values during 1090880 a B.P. and $260-190$ a B.P.

The five abnormally rapid sediment events are well corresponding with rich precipitation in Taiwan. The rapid accumulation event of $6790-6600$ a B.P. possibly occurs under the condition of Climate Warm Period in the Holocene. Pollen data of mountain area in the middle of Taiwan show that during the period of $6900-6800$ a B.P., peak value of spore maybe indicates an event with high precipitation ${ }^{[53]}$. AMS ${ }^{14} \mathrm{C}$ data of paleo-tree in Gezhouba, Yichang indicate that there was a flood during the period of $6570 \pm 110$ a B.P. ${ }^{[54]}$. The period of $5690-5600$ a B.P. was a high frequency flood stage in the lower reaches of Changjiang River ${ }^{[55]}$. Multi-proxies including pollen, granularity, the scanning electric microscope of sediment from the Baohuashan area and embedding paleo-tree indicate that there was a mountainous flood during the period of $5720 \pm 80$ a B.P. ${ }^{[56]}$. The period of $4820-4720$ a B.P. in the pre-history in China is characterized with the high frequency occurrence of flood. $1090-880$ a B.P. is a period from Emperor Tang Yizong (859-873 AD) to Emperor Song Shenzong (1067-1085 AD). Historical materials show that the Song and Yuan Dynasties (960$1368 \mathrm{AD})$ were an unstable period when the climate fluctuated continually, and the period of $1000-800$ a B.P. was the third cold stage in China, in which eighteen flood events occurred. $260-190$ a B.P. is just between the period of the so-called Little Ice Age (LIA). Moreover, historical materials showed that in the period of 500100 a B.P. there were 52 floods events, 40 of which occurred in the LIA.

Located in the collision zone between the EuropeAsia Continental Plate and Philippine Sea Plate, high frequencies of structure and earthquake activities occurred in Taiwan, and about ten earthquakes with magnitude $M_{\mathrm{s}}>5$ occurred in the study area per year. Moreover, because the slope north of the I-Lan Shelf is very 
very steep $\left(>3^{\circ}\right)$, the surface sediment on the slope is readily unstable and then subject to resuspension or slumping once large earthquakes strike. High frequency earthquake activities maybe have a direct or indirect influence on the sedimentation in the study area, making sediment accumulated in the continental shelf and continental slope resuspend and transmit toward deep-water are ${ }^{[57]}$. There are no obvious turbidity layers in core MD05-2908. However, several coarse-grained interbeddings with different thickness were observed in the core. Moisture content data show that it is low in the interlayer and decades of little coarse-grained veins can be identified by the change of moisture content, which is coincident with the results by grain size analysis. This confirms that decades-scale high-rate sedimentation events recorded in the MD05-2908 core since the mid-Holocene may be caused by earthquakes, storms or tsunamis.

\section{Conclusions}

With sedimentation rates substantially higher than those observed elsewhere in the Okinawa Trough along the route of Kuroshio, the SOT area is probably the most effective sink of sediments from Taiwan and the East China Sea shelf. With core MD05-2908 from the SOT,

1 Thompson P R. Planktonic foraminifera in the western North Pacific during the past 150000 years: comparison of modern and fossil assemblages. Paleogeogr Paleoclimatol Paleoecol, 1981, 4: 241-279[DOI]

2 Shieh Y T, Wang C H, Chen M P, et al. The last glacial maximum to Holocene environment changes in the southern Okinawa Trough. J Asian Earth Sci, 1997, 15(1): 3-8

3 Li B H, Jian Z M, Wang P X. Pulleniatina obliquiloculata as paleoceanogrphic indicator in the southern Okinawa Trough during the last 20000 years. Mar Micropaleontol, 1997, 32: 59-69[DOI]

4 Li T G, Liu Z X, Michael A, et al. Heinrich event imprints in the Okinawa Trough: evidence from oxygen isotope and planktonic foraminifera. Paleogeogr Paleoclimatol Paleoecol, 2001, 176: $133-146[\mathrm{DOI}]$

5 Cang S X, Yan J. Paleoceanography of Special Area in West Pacific (in Chinese). Qingdao: Qingdao Press, 1992

6 Jian Z M, Li B H, Pflauman U, et al. Late Holocene cooling event in the western Pacific (in Chinese). Sci China Ser D-Earth Sci, 1996, 26(5): 461-466

7 Liu Z X, Saito Y, Li T G, et al. The millennial-scale paleoceanographic study of the Okinawa Trough since the late Quaternary (in Chinese). Chin Sci Bull, 1999, 44(8): 883-887

8 Liu Z X, Li P Y, Li T G, et al. Paleoenvironmental change in the Okinawa Trough during the past 50000 years (in Chinese). Chin Sci Bull, 2000, 45(16): 1776-1781

9 Meng X W, Liu Y G, Liu Z X, et al. The water temperature、salinity in surface layer and the restore of $\mathrm{CO}_{2}$ in atmosphere and their ancient we identified the high sedimentation rate of about 5 $\mathrm{m} / \mathrm{ka}$ since the middle Holocene and five periods of abnormally rapid sedimentation events, during which the highest sedimentation rate is up to $21.2 \mathrm{~m} \mathrm{ka}^{-1}$. Such high sedimentation rates are unprecedented in the Okinawa Trough and somewhat unexpected. The sediments of MD05-2908 were dominated by silt and clay, associated with less than $5 \%$ coarse size fraction. Today, fluvial runoff from the mountain ranges of Taiwan is the main source of detrital sediment supply to the southern Okinawa Trough, resulting from high erosional gradients and heavy summer rain falls. In addition to the permanent processes of sediment supply, episodic events cause downslope sediment transport from the margins of the southern Okinawa Trough through mass wasting and density currents, triggered by earthquakes, typhoons, or heavy floods in the terrestrial hinterland. The five abnormally rapid sediment events are caused mainly by the abundance rainfall, moreover, the little coarse-grained veins may be caused by earthquakes, storms or tsunamis.

We are grateful to crews aboard the Marco Polo 2 cruise of the $R / V$ Marion Dufresne, We especially thank Prof. Liu Jingpu and other two reviewers for their comments and constructive criticisms on the manuscript.

climate significance in Okinawa trough during Holocene (in Chinese). Chin Sci Bull, 2001, 46(S1): 80-83

10 Wei K Y. LEG 195 Synthesis: Site 1202-Late Quaternary sedimentation and paleoceanography in the Southern Okinawa Trough. In: Shinohara M, Salisbury M H, Richter C, eds. Proceedings of the Ocean Drilling Program, Scientific Results, 2006, 195(3): 1-31

11 Chung Y, Chang W C. Pb-210 fluxes and sedimentation rates on the lower continental slope between Taiwan and the South Okinawa Trough Cont Shelf Res, 1995, 15: 149-164

12 Shipboard Scientific Party. In Salisbury M H, Shinohara M, Richter C, et al. Proc. ODP, Init. Repts., 195, 1-46 [CD-ROM]. Available from: Ocean Drilling Program, Texas A \& M University, College Station TX 77845-9547, 2002 USA

13 Chen S K. Sediment accumulation rates and organic carbon deposition in the East China Sea Continental Margin sediments. M. S. Thesis, Taiwan University, Taipei, Taiwan, 1995. 80

14 Jeng W L, Chen M P. Grain size effect on bound lipids in sediments off northeastern Taiwan. Org Geochem, 1995, 23: 301-310[DOI]

15 Chen M P, Lin K L, Huang C K. Sedimentary structure and texture of surficial sediment off northeastern Taiwan (in Chinese with English abstract). Ti-Chih (ROC), 1995, 15: 15-47

16 Sheu D D, Jou W C, Chung Y C, et al. Geochemical and carbon isotopic characterization of particles collected in sediment traps from the East China Sea continental slope and the Okinawa Trough northeast of Taiwan. Con Shelf Res, 1999, 19: 183-203[DOI]

17 Jeng W L, Huh C A. A comparison of sedimentary aliphatic hydrocarbon distribution between the southern Okinawa Trough and a 
nearby river with high sediment discharge. Estu Coastal Shelf Sci, 2006, 66: 217-224[DOI]

18 Huh C A, Su C C, Wang C H, et al. Sedimentation in the Southern Okinawa Trough - Rates, turbidities and a sediment budget. Mar Geol, 2006, 231: 129-139[DOI]

19 Jeng W L. Aliphatic hydrocarbon concentrations in short sediment cores from the southern Okinawa Trough: Implications for lipid deposition in a complex environment. Con Shelf Res, 2007, 27: 2066-2078[DOI]

20 Kao S J, Lin F J, Liu K K. Organic carbon and nitrogen contents and their isotopic compositions in surficial sediments from the East China Sea shelf and the southern Okinawa Trough. Deep-Sea Res II, 2003, 50: $1203-1217[$ DOI]

21 Hsu S C, Lin F J, Jeng W L. The effect of a cyclonic eddy on the distribution of lithogenic particles in the southern East China Sea. J Mar Res, 1998, 56: 813-832[DOI]

22 Hsu S C, Lin F J, Jeng W L, et al. Observed sediment fluxes in the southwesternmost Okinawa Trough enhanced by episodic events: flood runoff from Taiwan rivers and large earthquakes. Deep-Sea Res, Part I, 2004, 51: 979-997

23 Stuiver M, Reimer P J, Bard E. INTCAL98 Radiocarbon age calibration 24000-0 cal BP. Radiocarbon, 1998, 40: 1041-1083

24 Ujiié Y, Ujjié H, Taira A, et al. Spatial and temporal variability of surface water in the Kuroshio source region, Pacific Ocean over the past 21000 years: Evidence from planktonic foraminifera. Mar Micropaleontol, 2003, 49: 335-364[DOI]

25 Jian Z, Li B, Huang B, et al. Globorotalia trucatulinoides as indicator of upper-ocean thermal structure during the Quaternary: Evidence from the South China Sea and Okinawa Trough. Palaeogeogr Palaeoclimatol Palaeoecol, 2000, 162: 287-298[DOI]

26 Baker E T, Hickey B M. Contemporary sedimentation processes in and around an active west coast submarine canyon. Mar Geol, 1986, 71: 15-34[DOI]

27 Gardner W D. Baltimore Canyon as a modern conduit of sediment to the deep sea. Deep-Sea Res, 1989, 36: 323-358[DOI]

28 Monaco A, Courp T, Heussner S, et al. Seasonality and composition of particulate fluxes during ECOMARGE-I, western Gulf of Lions. Cont Shelf Res, 1990, 10: 959-987[DOI]

29 Tommaso T, Stefano M, Miguel A, et al. Source, transport and fate of terrestrial organic carbon on the western Mediterranean Sea, Gulf of Lions, France. Mar Chem, 2007, 105(2): 101 - 117[DOI]

30 Biscaye P E, Anderson R F, Deck B L. Fluxes of particles and constituents to the eastern United States continental slope and rise: SEEP-I. Cont Shelf Res, 1988, 8: 855-904[DOI]

31 Biscaye P E, Anderson R F. Fluxes of particulate matter on the slope of the southern Middle Atlantic Bight: SEEP-II. Deep-Sea Research II, 1994, 41: 459-509[DOI]

32 Dadson S J. Links between erosion, runoff variability and seismicity in the Taiwan orogen. Nature, 2003, 426: 648-651[DOI]

33 Jeng W L, Lin S, Kao S J. Distribution of terrigenous lipids in marine sediments off northeastern Taiwan. Deep-Sea Res, Part II, 2003, 50: $1179-1201$

34 Liu K K, Peng T H, Shaw P T, et al. Circulation and biogeochemical processes in the East China Sea and the vicinity of Taiwan: An overview and a brief synthesis. Deep-Sea Res, Part II, 2003, 50: $1055-1064$

35 Hong K Z. Settling particulates on the continental slope off northeast Taiwan: mass flux, grain size distribution and disequilibrium between lead-210 and polonium-210 (in Chinese). M. S. Thesis, Kaohsiung: Institute of Marine Geology and Chemistry, Sun Yat-sen University, Taiwan, 1995. 80

36 Chen M P, Lo S C, Lin K L. Composition and texture of surface sediment indicating the depositional environments off Northeast Taiwan (in Chinese). Terrestrial Atmos Oceanic Sci, 1992, 3(3): $395-417$
37 Lin K L. Sedimentary structure, texture and clay minerals of surficial sediments off northeastern Taiwan (in Chinese). M.S. Thesis, Taipei: Institute of Oceanography, Taiwan University, 1992

38 Liu J P, Li A C, Xu K H, et al. Sedimentary features of the Yangtze River-derived along-shelf clinoform deposit in the East China Sea. Cont Shelf Res, 2006, 26: 2141 - 2156[DOI]

39 Liu J P, Xu K H, Li A C, et al. Flux and fate of Yangtze River sediment delivered to the East China Sea. Geomorphology, 2007, 85: 208 - 224[DOI]

40 Zhang X L. A preliminary study of the distribution and characteristics of the sediments on Ilan shelf (in Chinese). M.S. Thesis, Taipei: Institute of Oceanography, Taiwan University, 2003

41 Chung Y, Huang G W. Particulate fluxes and transports on the slope between the southern East China Sea and the South Okinawa Trough. Cont Shelf Res, 2000, 20: 571 - 597[DOI]

42 Deuser W G, Ross E H, Anderson R F. Seasonality in the supply of sediment to the deep Sargasso Sea and implications for the rapid transfer of matter to the deep ocean. Deep Sea Res Part A, Oceanographic Research Papers, 1981, 28(5): 495-505[DOI]

43 Deuser W G, Ross E H, Hemleben C, et al. Seasonal changes in species composition, numbers, mass, size, and isotopic composition of planktonic foraminifera settling into the deep Sargasso sea. Palaeogeogr Palaeoclimatol Palaeoecol, 1981, 33(1): 103-127[DOI]

44 Ramaswamy V, Nair R R, Manganini S, et al. Lithogenic fluxes to the deep Arabian sea measured by sediment traps. Deep Sea Res Part A, Oceanographic Research Papers, 1991, 38(2): 169-184[DOI]

45 Robert A. Wheat croft. Oceanic flood sedimentation: a new perspective. Cont Shelf Res, 2000, 20(16): 2059-2066[DOI]

46 Andre M, Pierre B, Jacques S. Particle fluxes and ecosystem response on a continental margin: the 1985-1988 Mediterranean ECOMARGE experiment. Cont Shelf Res, 1990, 10(9-11): 809-839[DOI]

47 Pierre E, Biscaye, Robert F. Fluxes of particulate matter on the slope of the southern Middle Atlantic Bight: SEEP-II. Deep Sea Res Part II: Topical Studies in Oceanography, 1994, 41(2-3): 459-509[DOI]

48 Walsh J P, Nittrouer C A. Observations of sediment flux to the Eel continental slope, northern California. Mar Geol, 1999, 154(1-4): 55-68[DOI]

49 Hung J J, Lin C S, Hung G W, et al. Lateral transport of lithogenic particles from the continental margin of the southern East China Sea. Estu Coastal Shelf Sci, 1999, 49: 483-499[DOI]

50 Kao S J, Liu K K. Estimating the suspended sediment load by using the historical hydrometric record from the Lanyang-Hsi watershed. Terrestrial Atmos Oceanic Sci, 2001, 12: 401-414

51 Milliman J D, Kao S J. Hyperpycnal discharge of fluvial sediment to the ocean: impact of Super-typhoon Herb (1996) on Taiwanese Rivers. J Geol, 2005, 113: 503-516[DOI]

52 Milliman J D, Syvitski J P. Geomorphic tectonic control of sediment discharge to the ocean - The importance of small mountainous rivers. J Geol, 1992, 100: 525-544

53 Liew P M, Lee C Y, Kuo C M. Holocene thermal optimal and climate variability of East Asian monsoon inferred from forest reconstruction of a subalpine pollen sequence, Taiwan. Earth Planet Sci Lett, 2006, 250: 596-605[DOI]

54 Zhou F Q. Discuss the New Tectonic Movement Characteristics and Ancient Geographic Environment From the Excavating of Honghuatao Site (in Chinese). Wuhan: Wuhan University Press, 1990

55 He H C, Wang Y, Li S H. Tracing flood water level along Nanjing cliff bank of the Yangtze River (in Chinese). Acta Geogr Sin, 2004, 59(6): $938-947$

56 Zhu C, Yu S Y, Zhang B, et al. Study on Holocene sedimentary environment in Baohuashan area of Nanjing (in Chinese). Acta Geogr Sin, 1997, 17(3): 253-258

57 Huh C A, Su C C, Liang W T, et al. Linkages between turbidities in the southern Okinawa Trough and submarine earthquakes. Geophys Res Lett, 2004, 31: L12304[DOI] 